\title{
Estimates of Nitrate Loads and Yields From Groundwater to Streams in the Chesapeake Bay Watershed Based on Land Use and Geology
}

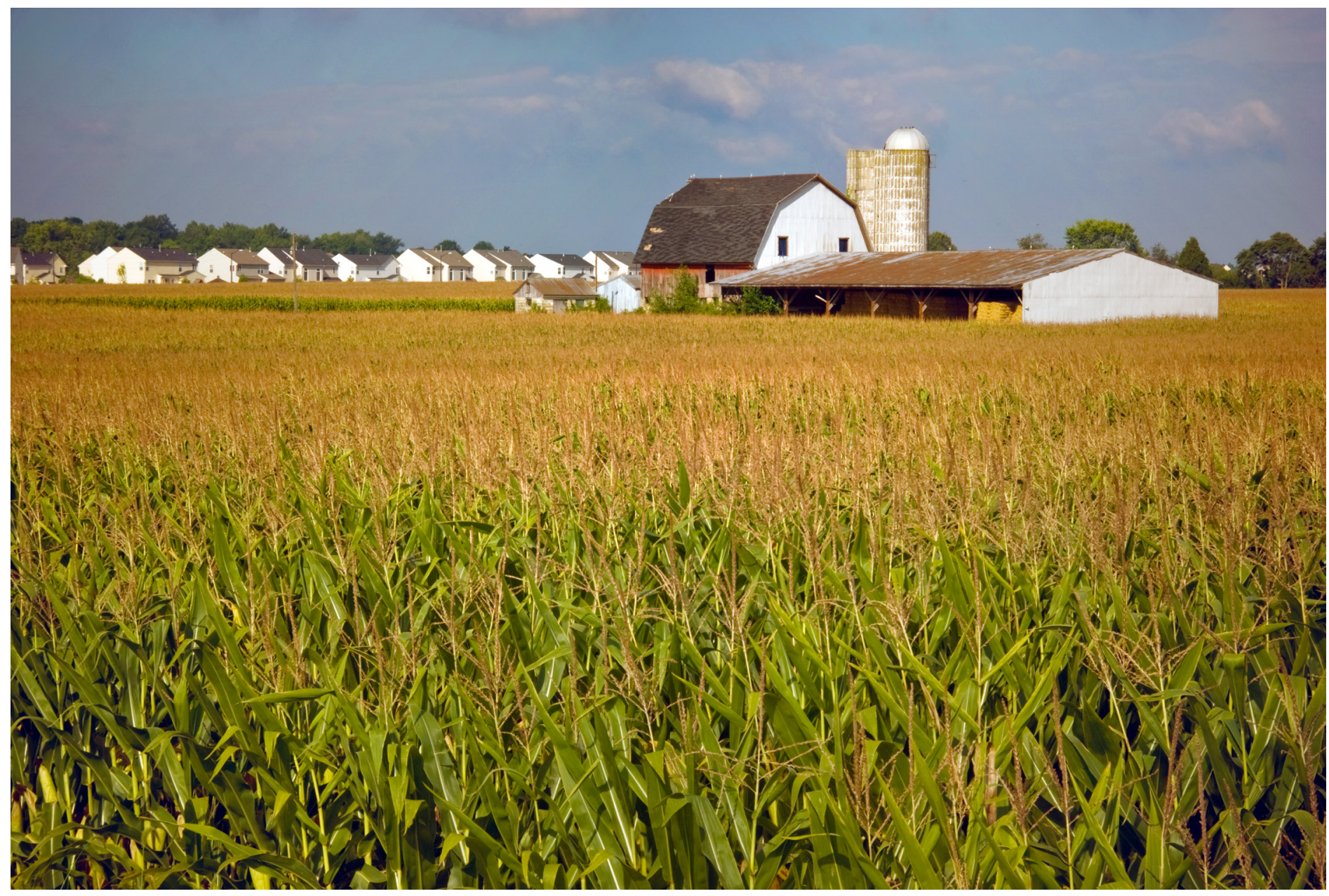

Scientific Investigations Report 2017-5160 
Cover. Agricultural land within the Chesapeake Bay watershed in Easton, Maryland. Photograph by U.S. Department of Agriculture. 


\section{Estimates of Nitrate Loads and Yields From Groundwater to Streams in the Chesapeake Bay Watershed Based on Land Use and Geology}

By Silvia Terziotti, Paul D. Capel, Anthony J. Tesoriero, Jessica A. Hopple, and Scott C. Kronholm

Scientific Investigations Report 2017-5160 


\title{
U.S. Department of the Interior \\ RYAN K. ZINKE, Secretary
}

\section{U.S. Geological Survey William H. Werkheiser, Deputy Director exercising the authority of the Director}

\author{
U.S. Geological Survey, Reston, Virginia: 2018
}

For more information on the USGS - the Federal source for science about the Earth, its natural and living resources, natural hazards, and the environment-visit https://www.usgs.gov or call 1-888-ASK-USGS.

For an overview of USGS information products, including maps, imagery, and publications, visit https://store.usgs.gov.

Any use of trade, firm, or product names is for descriptive purposes only and does not imply endorsement by the U.S. Government.

Although this information product, for the most part, is in the public domain, it also may contain copyrighted materials as noted in the text. Permission to reproduce copyrighted items must be secured from the copyright owner.

Suggested citation:

Terziotti, Silvia, Capel, P.D., Tesoriero, A.J., Hopple, J.A., and Kronholm, S.C., 2018, Estimates of nitrate loads and yields from groundwater to streams in the Chesapeake Bay watershed based on land use and geology: U.S. Geological Survey Scientific Investigations Report 2017-5160, 20 p., https://doi.org/10.3133/sir20175160.

ISSN 2328-0328 (online) 


\section{Contents}

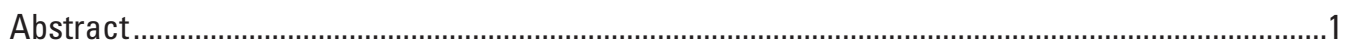

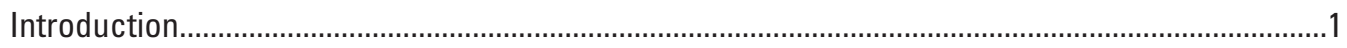

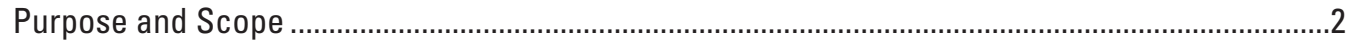

Study Area

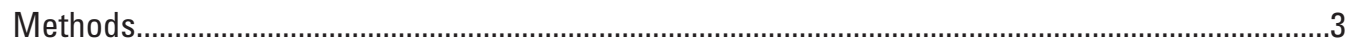

Data Development for Median Baseflow Nitrate Concentrations in Streams at

Calibration Sites ...........................................................................................................

Site and Data Selection for Nitrate Water Quality ............................................................

Calculating Long-Term Baseflow Nitrate Concentrations from Sampled Streams ..........3

Characterization of Land Cover and Geology ………..........................................................

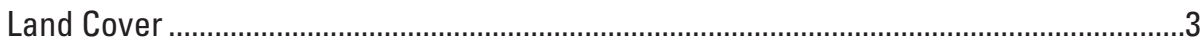

Geologic Formations ...........................................................................................

Development of a Regression Equation to Relate Median Baseflow Nitrate Concentrations to Land Use and Underlying Geology ................................................5

Extrapolation of Median Baseflow Nitrate Concentrations to Loads and Yields for All of the Chesapeake Bay Watershed ..................................................................................

Sources of Geospatial Information ..............................................................................

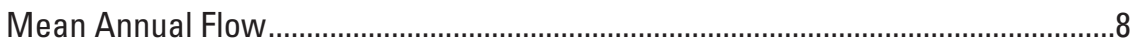

Percent Developed and Percent Agricultural.........................................................

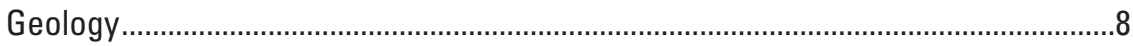

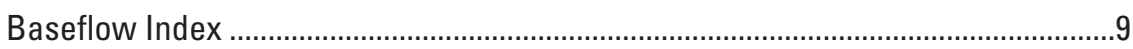

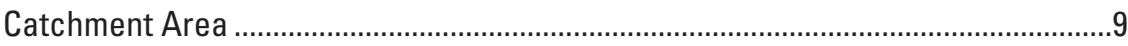

Calculating Median Nitrate Concentrations in Baseflow, Loads, and Yields From

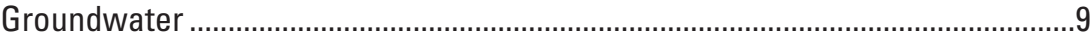

Results of Estimated Nitrate Loads and Yields From Groundwater to Streams ..............................11

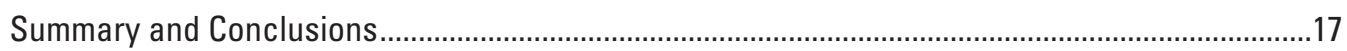

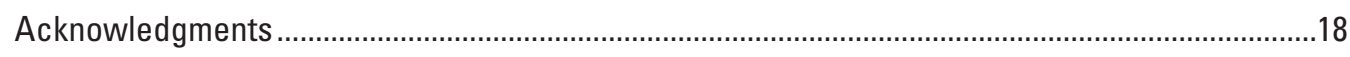

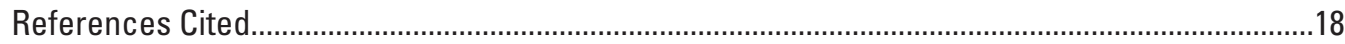

\section{Figures}

1. A generalized schematic of flow paths and lag times associated with transport of nitrate in groundwater in shallow flow systems in the surficial aquifer to streams .............................................................................................

2. Map showing water-quality sampling site locations, Chesapeake Bay watershed .........4

3. Map showing land cover classes of the Chesapeake Bay watershed .............................6

4. Map showing generalized areas of the principal aquifers in the Chesapeake Bay watershed

5. Graph showing actual median nitrate concentrations in baseflow compared with estimated median nitrate concentrations in baseflow, based on model results

6. Boxplots of actual and estimated baseflow concentrations of nitrate by geologic unit 
7. Maps showing estimated groundwater nitrate for each catchment within the Chesapeake Bay watershed, annual median concentration, annual load

from groundwater to streams, and annual yield from groundwater

8. Maps showing estimated groundwater nitrate for each catchment within the Chesapeake Bay watershed, annual load from groundwater to streams, and annual yield from groundwater

9. Maps showing the comparison of groundwater nitrate yield to SPAtially Referenced Regressions On Watershed attributes (SPARROW) model total nitrogen yield, kilograms per square kilometer

\section{Tables}

1. Regression coefficients and $p$-values for the model to predict median baseflow nitrate concentration, Chesapeake Bay watershed

2. Long-term mean and median baseflow values, actual and estimated, by regression model and geologic unit.

3. Variables used to estimate median nitrate concentration in baseflow for catchments within the Chesapeake Bay watershed 


\title{
Estimates of Nitrate Loads and Yields from Groundwater to Streams in the Chesapeake Bay Watershed Based on Land Use and Geology
}

\author{
By Silvia Terziotti, Paul D. Capel, Anthony J. Tesoriero, Jessica A. Hopple, and Scott C. Kronholm
}

\section{Abstract}

The water quality of the Chesapeake Bay may be adversely affected by dissolved nitrate carried in groundwater discharge to streams. To estimate the concentrations, loads, and yields of nitrate from groundwater to streams for the Chesapeake Bay watershed, a regression model was developed based on measured nitrate concentrations from 156 small streams with watersheds less than 500 square miles $\left(\mathrm{mi}^{2}\right)$ at baseflow. The regression model has three predictive variables: geologic unit, percent developed land, and percent agricultural land. Comparisons of estimated and actual values within geologic units were closely matched. The coefficient of determination $\left(\mathrm{R}^{2}\right)$ for the model was 0.6906 . The model was used to calculate baseflow nitrate concentrations at over 83,000 National Hydrography Dataset Plus Version 2 catchments and aggregated to 1,966 total 12-digit hydrologic units in the Chesapeake Bay watershed. The modeled output geospatial data layers provided estimated annual loads and yields of nitrate from groundwater into streams. The spatial distribution of annual nitrate yields from groundwater estimated by this method was compared to the total watershed yields of all sources estimated from a Chesapeake Bay SPAtially Referenced Regressions On Watershed attributes (SPARROW) water-quality model. The comparison showed similar spatial patterns. The regression model for groundwater contribution had similar but lower yields, suggesting that groundwater is an important source of nitrogen for streams in the Chesapeake Bay watershed.

\section{Introduction}

Excess nitrate in streams can negatively impact the ecosystem health of streams, lakes, and estuaries (Dubrovsky and others, 2010) and increase costs to maintain sustainable fisheries, drinking water treatment, and recreational tourism (U.S. Environmental Protection Agency, Office of Water, 2015). Sources of nitrate include atmospheric deposition, wastewater, fertilizer, and manure. Nitrate loads entering the Chesapeake Bay have been monitored and modeled since the 1980s (Ator and others, 2011; Langland and others, 2013). Efforts to reduce nitrogen inputs into the bay have included improvements to wastewater treatment plants and the increased use of urban and agricultural management practices to reduce runoff (Chesapeake Bay Program, 2017a). These efforts have reduced nutrient loads entering the bay in recent years, but some reduction might be from lower-than-average flows into the rivers that drain into the bay (Chesapeake Bay Program, 2017b).

Two major challenges impede the benefits of management practices that reduce nitrate sources within the Chesapeake Bay: (1) lag times between implementation and water-quality improvements and (2) continued population growth and intensification of agriculture (Lyerly and others, 2014). Lag times occur because of the long residence times of nutrients in groundwater (Tesoriero and others, 2013). Nitrate in groundwater can be transmitted to streams during recharge at differing rates depending on the environmental setting (fig. 1). In the Piedmont and Coastal Plain provinces of the mid-Atlantic, stream baseflow is predominately groundwater and accounts for greater than 50 percent of the annual stream discharge (Wolock, 2003; Santhi and others, 2008). Groundwater plays a significant role as a pathway for nitrogen loading to stream networks that flow into the bay (Sanford and Pope, 2013).

Although nitrate contributions from groundwater to streams have been observed in various regions of the Chesapeake Bay watershed and nationwide (Denver and others, 2004; Debrewer and others, 2008; Dubrovsky and others, 2010), they are difficult to monitor and quantify. The estimated concentration and residence time of nitrate in baseflow also has been shown to be comparable to the aggregated groundwater quality within a watershed (Clune and Denver, 2012). By using land cover and geologic units to model the conditions for baseflow nitrate concentration, areas from which nitrate transport to streams is most likely to occur can be identified. This report builds upon previous modeling efforts to help resource managers prioritize and target areas for conservation practices. 


\section{Estimates of Nitrate From Groundwater to Streams in the Chesapeake Bay Watershed}

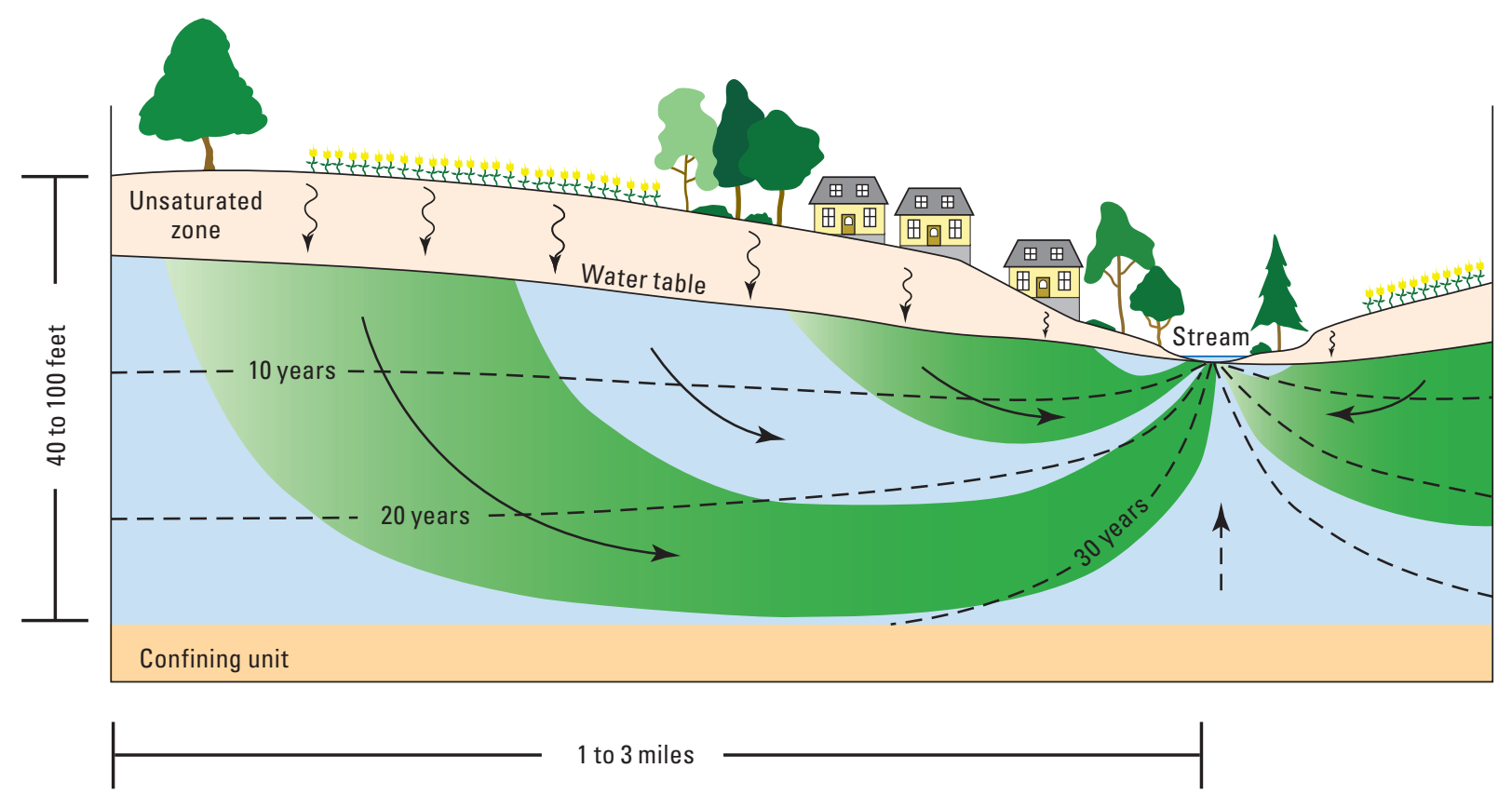

EXPLANATION

Nitrate from human sources

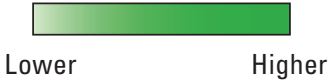

$\longrightarrow$ Direction of groundwater flow

-- Groundwater age

Figure 1. A generalized schematic of flow paths and lag times associated with transport of nitrate in groundwater in shallow flow systems in the surficial aquifer to streams. Adapted from Shedlock and others (1999).

\section{Purpose and Scope}

The purpose of this report is to quantify the average, median concentration, load, and yield of nitrate in groundwater for each stream reach across the Chesapeake Bay watershed. To meet these objectives, a statistical model for the watershed was developed with four components: (1) calculation of median stream baseflow nitrate concentrations at calibration sites within the watershed, (2) characterization of the land use and the underlying geology of the principal aquifers within the study area, (3) development of a regression equation to relate median baseflow nitrate concentrations to land use and underlying geology, and (4) extrapolation of the regression equation to all areas within the Chesapeake Bay watershed. Use of this model resulted in a geospatial data layer of the estimated annual loads and yields of nitrate from groundwater to streams. This approach can be reproduced for other areas of the country if there are sufficient observations of nitrate concentrations in streams at baseflow from those areas.

\section{Study Area}

The Chesapeake Bay is the largest estuary in the United States. The watershed that drains into the bay is 166,000 square kilometers $\left(\mathrm{km}^{2}\right)$ and drains from portions of six States (New York, Pennsylvania, West Virginia, Maryland, Delaware, and Virginia) and the District of Columbia. Over 18 million people live in the watershed, including the population centers of Washington D.C.; Baltimore, Maryland; Richmond, Virginia; and Harrisburg, Pennsylvania. The local population is growing steadily, with development centered along the bay's shores (Chesapeake Bay Program, 2017a). The five largest rivers that drain into the Chesapeake Bay are the Susquehanna, Potomac, Rappahannock, York, and James (Chesapeake Bay Program, 2017a). The watershed is primarily forested but also has areas of intensive agriculture (Ator and others, 2011).

The physiographic provinces that make up the watershed include the Coastal Plain, Piedmont, Blue Ridge, Valley and Ridge, and Appalachian Plateaus. The provinces span various topographic settings - from the flat coastal regions to the mountains and high slopes of the Appalachian region. The 30 -year normal precipitation is 43 inches, with a range of 31 inches per year in the western valleys of the Potomac and Susquehanna Rivers to over 55 inches per year in the ridges of Virginia (PRISM Climate Group, 2017). The mean maximum annual temperature ranges from less than 15 degrees Celsius in the higher altitude areas of New York and Pennsylvania to greater than 18.5 degrees Celsius on the coastal plain (Ator and others, 2011). 
The Chesapeake Bay and surrounding shores provide an estimated $\$ 33$ billion a year of economic and recreational benefits to the region from fishing, tourism, real estate, shipping, and various environmental sectors of the economy. The bay is also home to a wide variety of birds, plants, fish, shellfish, and mammals (Pew Charitable Trusts, 2017).

\section{Methods}

\section{Data Development for Median Baseflow Nitrate Concentrations in Streams at Calibration Sites}

The steps taken to calculate the median baseflow nitrate concentrations, loads from groundwater to streams, and watershed nitrate yields from groundwater are described in the following sections. The water-quality data were retrieved from the U.S. Geological Survey (USGS), and other resources, as nitrate plus nitrite $\left(\mathrm{NO}_{3}^{-}+\mathrm{NO}_{2}^{-}\right)$. Nitrate was always the major chemical species; therefore, this report uses the term "nitrate."

\section{Site and Data Selection for Nitrate Water Quality}

The water-quality information in this analysis came from surface-water data sites in the Chesapeake Bay watershed sampled by the USGS and partner agencies (Langland and others, 2013). These water-quality data were compiled into a working database by the authors. The selection of sites and the associated water-quality data included in the database were based on the minimum criteria described by Langland and others (1995). Their selection process yielded 1,276 nontidal water-quality sites within the Chesapeake Bay watershed, each with 50 or more nitrate samples. The drainage area of the contributing basin was retrieved or calculated for each site. Sites with drainage areas of less than $1,300 \mathrm{~km}^{2}$ were selected to avoid sites that contained drainage from an area so large that it might not represent local baseflow conditions.

The nitrate data from the Chesapeake Bay water-quality datasets and a separate data retrieval from the USGS National Water Information System (NWIS) Water-Quality System (Langland and others, 1995, 2013; U.S. Geological Survey, 2012) were combined. Only one sample per site, date, and time combination was retained. Because detailed information on sampling protocols exists for USGS data, these data were retained when samples with identical date-time records for the same site were collected by different agencies. The first sample for a given day was retained when several samples were reported for that day. Samples showing the remark code "V", which indicated samples affected by contamination, were removed from the dataset (Dupré and others, 2013). Samples reported with a concentration below the reporting limit for the constituent were retained. Once these criteria were satisfied, a final dataset of 156 gaged streams draining small watersheds (each draining less than $1,300 \mathrm{~km}^{2}$ ) — with greater than or equal to 50 samples of nitrate each and samples collected from 1970 to 2013 - was created (fig. 2).

\section{Calculating Long-Term Baseflow Nitrate Concentrations from Sampled Streams}

Baseflow is the component of streamflow attributable to groundwater discharge into streams, and the baseflow index (BFI) is the ratio of baseflow to total flow, expressed as a percentage. A BFI was estimated for each stream using a digital filter for hydrograph separation (Eckhardt, 2005); the details of the baseflow calculations are available in Raffensperger and others (2017). Annual baseflow was calculated for those water years (the 12-month period between October 1 and September 30) when 12 months of data were available and no more than 50 days of streamflow data were missing for that water year. For every day of missing streamflow, the median daily baseflow at the site was calculated for those days in each year and used as a substitute for days missing baseflow data. The daily baseflow was summed by year, and the median baseflow was calculated for all years combined (Raffensperger and others, 2017).

The median baseflow nitrate concentration was calculated using data from days when the baseflow index was greater than or equal to 0.7 ( 70 percent of the flow) for the stream (Raffensperger and others, 2017). The sample concentration was assumed to be zero when the reported value was below the detection limit (reported as "<" values). This decision led to consistently conservative estimates of median baseflow nitrate concentrations.

The median baseflow nitrate concentration is a surrogate for the concentration of nitrate in groundwater discharged into a stream. Nitrogen often transforms at the groundwatersurface-water interface and within the stream (Duff and others, 2008), so the median baseflow nitrate concentration is likely an underestimation of the nitrate concentration discharging from groundwater.

\section{Characterization of Land Cover and Geology}

The model applied to the Chesapeake Bay estimates the groundwater loading of nitrate to streams by using the classification of land cover on the surface of the Earth and the underlying geology of the principal aquifer in the watershed. The land cover category is used to identify potential sources of nitrate, and the underlying geology is used to explain how readily nitrate moves through the groundwater system and into streams (Winter and others, 1998; Sanford and Pope, 2013).

\section{Land Cover}

Agricultural (fertilizer, manure) and developed (fertilizer, wastewater, industrial discharges) land activities are the largest sources of nitrogen pollution to the Chesapeake Bay, 


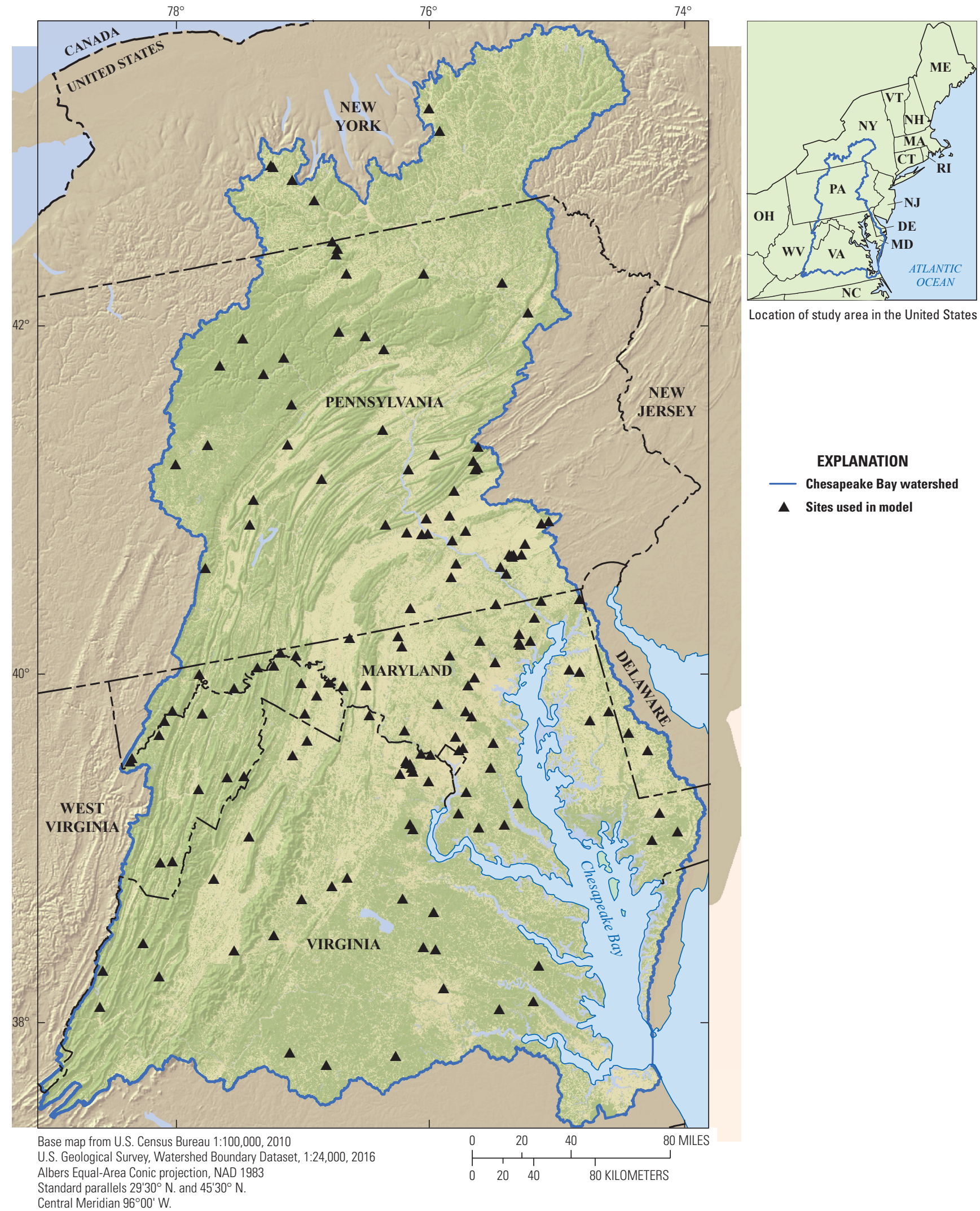

Figure 2. Map showing water-quality sampling site locations, Chesapeake Bay watershed. 
comprising over 50 percent of the total contribution (Ator and others, 2011). Agricultural land use practices are the primary sources of nonpoint pollution. Fertilizers-including manure - are applied to the land surface, where plant nutrient use is less than 100 percent of the nutrient applied (U.S. Department of Agriculture, 2016). The nutrient excesses on agricultural land allow the infiltration of nutrients into groundwater through leaching. Developed land sources are a combination of point and nonpoint contamination sources, often in high concentrations that can infiltrate the groundwater.

The 2011 National Land Cover Dataset (NLCD; Homer and others, 2015) land cover classes were grouped into three classes: "developed," "agricultural," and "other" (including water). The NLCD classes representing "developed" (21-open space; 22-low intensity; 23-medium intensity; and 24-high intensity) were grouped into one "developed" class. An "agricultural" class contains the lands in the planted and cultivated categories in the NLCD (81-pasture/hay and 82-cultivated crops). The remaining land cover classes (barren, forest, shrubland, herbaceous, wetland, water) were grouped into the "other" class (Homer and others, 2015). "Agricultural" and "developed" are the two land cover classes that contribute the majority of nitrate to groundwater baseflow. The "other" class represents unlikely sources of groundwater contamination (fig. 3).

\section{Geologic Formations}

The principal aquifers within the Chesapeake Bay watershed are defined by their predominant geologic formations. The physical properties of the geology influence how contaminants travel from the land surface, through the subsurface, and into surface-water systems (receiving waters). Based on their principal aquifer components, the USGS uses five different rock types and an "other" classification to divide the Chesapeake Bay watershed into categories (U.S. Geological Survey, 2003). The five geologic units that characterize the Chesapeake Bay watershed are carbonate, igneous and metamorphic, sandstone, sandstone and carbonate, and semiconsolidated sand. The "other" category within the principal aquifers map encompasses much of the northern section of the study area. The surficial geologic map (Greene and others, 2005) identifies the "other" area as primarily siliciclastic geology; therefore, the unit was renamed siliciclastic for this study. Because a high degree of nitrate transport to groundwater on the Delmarva Peninsula was measured in previous studies (Denver and others, 2004), a seventh geologic category"Delmarva"-was added to categorize the peninsula (fig. 4).

These geologic units have differing physical characteristics that affect their ability to transmit water. Siliciclastic rock, found in the northern portion of the watershed, is made up of shale, quartz, and other sedimentary rocks that have low hydraulic conductivity. Carbonate rock forms a small portion of the watershed, but it can have significant faults and fractures that allow constituents to move quickly from the surface and through the water table. Sandstone rock makes up a small part of the watershed and often has low-to-moderate hydraulic conductivity. Sandstone and carbonate rock underlies the west-central portion of the watershed. The aquifer underlying this area is composed of carbonate rocks mixed with sandstone and has characteristics similar to carbonate deposits. The south-central portion of the watershed is composed of igneous and metamorphic rock aquifers. Although the unit is primarily made of crystalline rocks with low porosity, it can be highly fractured and allow significant water movement. The igneous and metamorphic rocks, and carbonate rocks, are more likely than other units in the watershed to contain oxic groundwater (Tesoriero and others, 2015), a condition favorable to nitrate transport. The semiconsolidated sand unit is made of fine sand that drains to the bay and the coarser coastal plain to the west. The Delmarva portion has sediments that are typically coarse grained and found on the glacial outwash peninsula between the Atlantic Ocean and the Chesapeake Bay.

\section{Development of a Regression Equation to Relate Median Baseflow Nitrate Concentrations to Land Use and Underlying Geology}

Stepwise, multiple-linear regression was used to develop relations between predictor variables and baseflow nitrate concentrations using the PROC REG statement in the Statistical Analysis Software (SAS; SAS Institute, Inc., 2011). The predictor variables considered for estimating baseflow nitrate concentration within the Chesapeake Bay watershed were percent developed land within the watershed, percent agricultural land within the watershed, and geologic composition of the principal aquifer unit (represented by seven classes; see (table 1). The geologic classification is a categorical classification: "1" if the class represented the predominant geology within the watershed, " 0 " if it did not. Variables selected for the regression model (using a p-value $<0.1$ ) were percent agricultural; percent developed; carbonate; sandstone and carbonate; igneous and metamorphic; and Delmarva (table 1).

Of the four geologic classes used in the regression model, carbonate had the highest positive coefficient (table 1). This result indicated that higher concentrations of nitrate in baseflow were likely within this unit when sources were present than in the remaining units. For similar land use, the model indicates lower baseflow concentrations of nitrate for the Delmarva, igneous and metamorphic, and sandstone and carbonate geologic units than for the carbonate unit. The geologic units not included in the model — sandstone, semiconsolidated sand, and siliciclastic — show baseflow concentrations of nitrate based on the intercept, and percent developed and agricultural land, and tend to have lower concentrations than the other units.

The measured, long-term range of the median annual baseflow nitrate-concentration values was greater than the estimated values from the regression model. A maximum value 


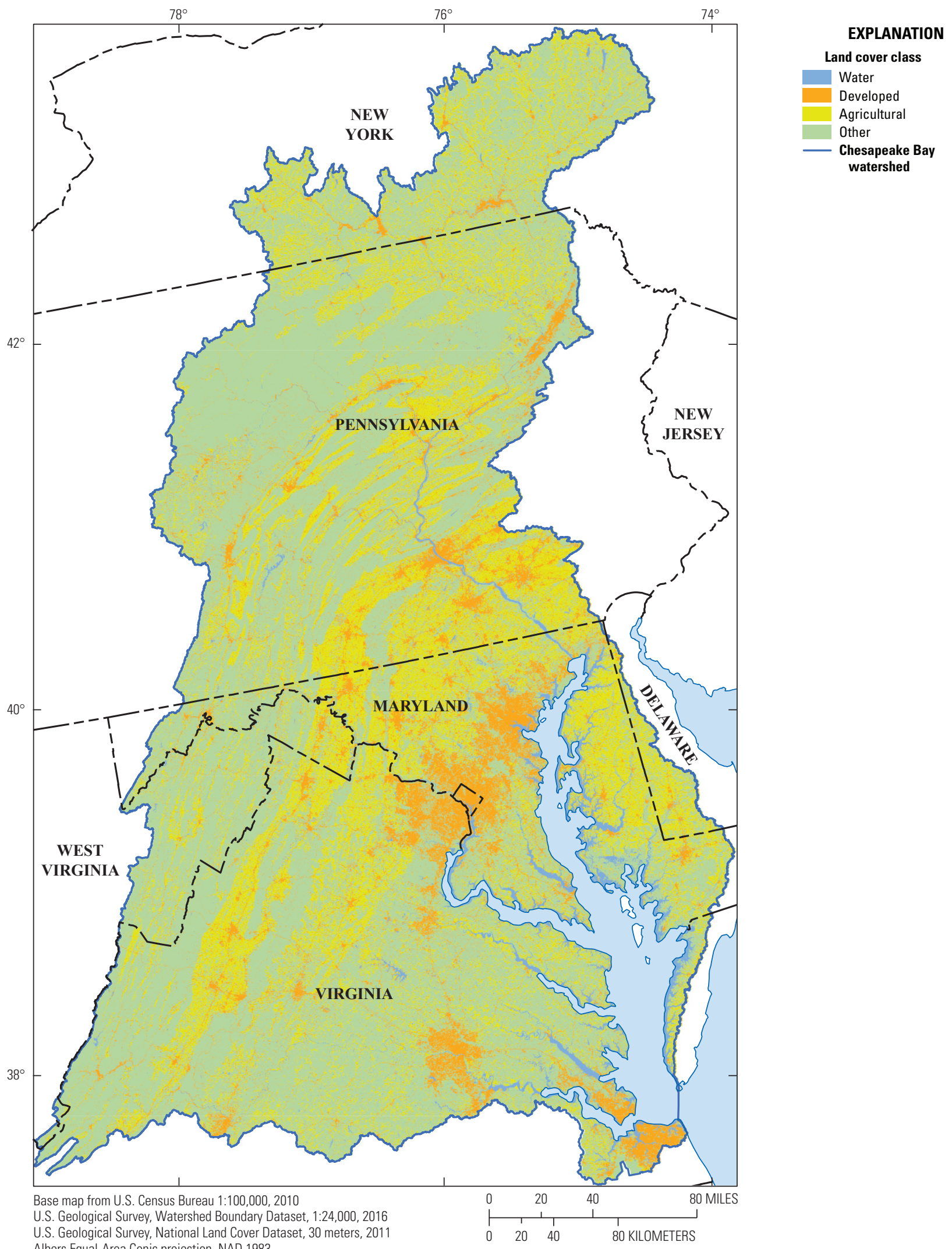

Standard parallels $29^{\prime} 30^{\circ} \mathrm{N}$. and $45^{\prime} 30^{\circ} \mathrm{N}$. Central Meridian $96^{\circ} 00^{\prime} \mathrm{W}$.

Figure 3. Map showing land cover classes of the Chesapeake Bay watershed. Water is shown as a separate category for better visual identification in the study area, but is included in the "other" class for the model. 


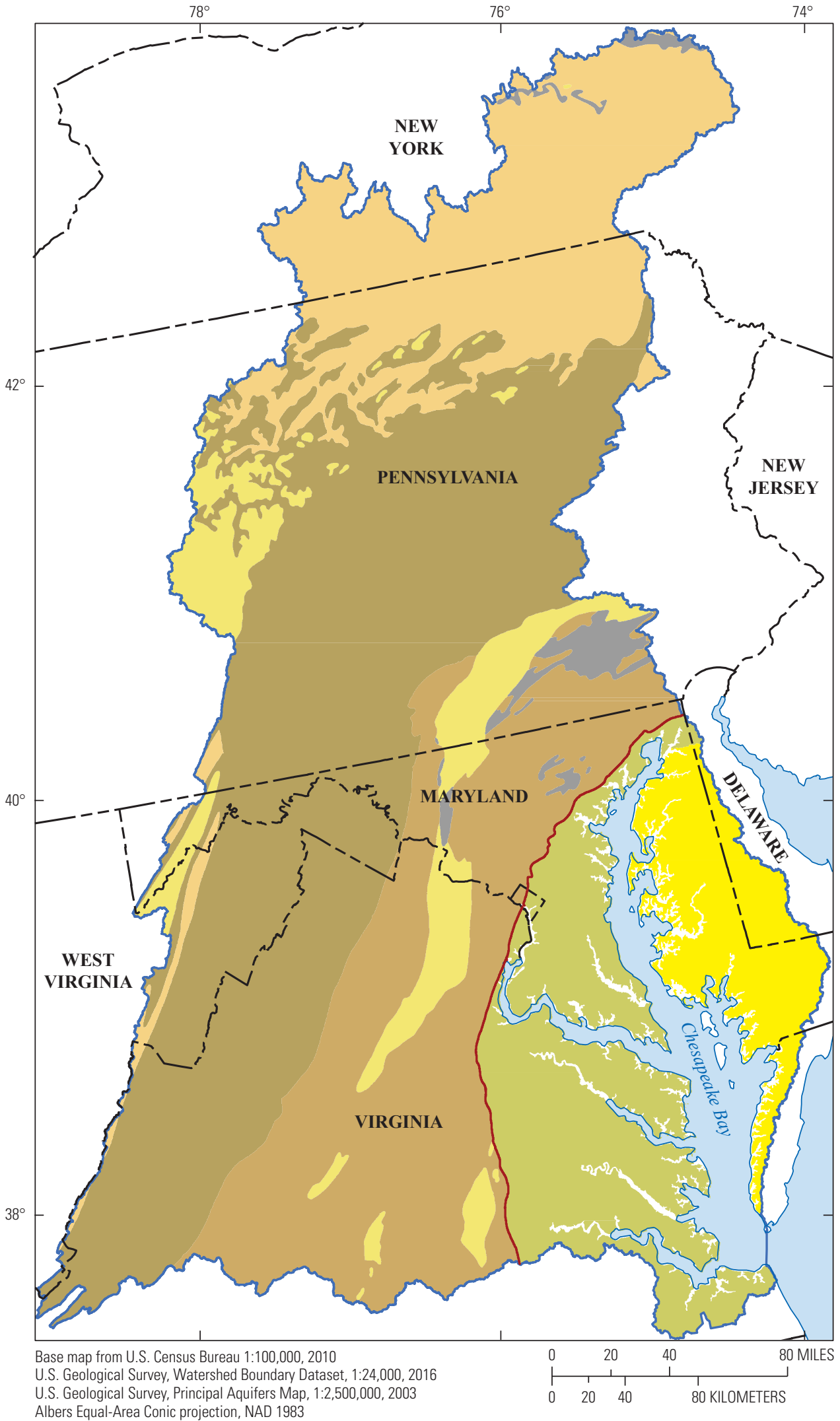

EXPLANATION

Geologic composition

Carbonate rock

Delmarva

Igneous and metamorphic

Sandstone

Sandstone and carbonate

Semiconsolidated sand

Siliciclastic

Chesapeake Bay

watershed

Coastal Plain line

Standard parallels $29^{\prime} 30^{\circ} \mathrm{N}$. and $45^{\prime} 30^{\circ}$ N., Central Meridian $96^{\circ} 00^{\prime} \mathrm{W}$.

Figure 4. Map showing generalized areas of the principal aquifers in the Chesapeake Bay watershed. 


\section{Estimates of Nitrate From Groundwater to Streams in the Chesapeake Bay Watershed}

Table 1. Regression coefficients and $p$-values for the model to predict median baseflow nitrate concentration, Chesapeake Bay watershed.

[Coefficient of determination $\left(\mathrm{R}^{2}\right)=0.6906 ;<$, less than]

\begin{tabular}{lcl}
\hline \multicolumn{1}{c}{ Variable } & $\begin{array}{c}\text { Regression } \\
\text { coefficient }\end{array}$ & p-value \\
\hline Intercept in figure 5 & -0.1302 & 0.61 \\
Percent developed & 0.00870 & 0.072 \\
Percent agriculture & 0.03463 & $<.0001$ \\
Carbonate & 6.05708 & $<.0001$ \\
Sandstone and carbonate & 0.49983 & 0.071 \\
Igneous and metamorphic & 0.84704 & 0.0071 \\
Delmarva & 1.36573 & 0.0074 \\
\hline
\end{tabular}

of 11.8 milligrams of nitrate per liter $(\mathrm{mg} \mathrm{N} / \mathrm{L})$ was measured for the sites; $9.2 \mathrm{mg} \mathrm{N} / \mathrm{L}$ was the maximum for the estimated values. The model equation has an $\mathrm{R}^{2}$ value of 0.6906 (fig. 5).

When comparing values from different geologic units, there is agreement between the mean nitrate concentrations observed at baseflow and the mean nitrate concentrations estimated by the model (table 2). However, the estimated median is higher than the actual mean in each of the geologic units, excepting the carbonate unit (table 2). The boxplots in figure 6 display the range of values for each geologic unit, both actual and estimated. Nearly all estimated values are within the $25^{\text {th }}-75^{\text {th }}$ percentile of the measured values for each geologic unit. The "other" category includes the geologic units not assigned a coefficient in the model equation.

\section{Extrapolation of Median Baseflow Nitrate Concentrations to Loads and Yields for All of the Chesapeake Bay Watershed}

The annual baseflow nitrate concentration for all streams was estimated by taking the regression formula developed for the 156 watersheds and applying it to the National Hydrography Dataset Plus Version 2 (NHDPlusV2) catchments within the Chesapeake Bay watershed (Horizon Systems Corporation, 2017). The catchments were then aggregated to hydrologic units defined by the Watershed Boundary Dataset 12-digit hydrologic unit code (HUC12) (U.S. Geological Survey and U.S Department of Agriculture, Natural Resources Conservation Service, 2013). Concentrations calculated by the regression equation were converted to loads and yields for each catchment and HUC12 basin. The variables used to calculate the load and yield values are described below.

\section{Sources of Geospatial Information}

Each catchment within the Chesapeake Bay watershed was extracted from the mid-Atlantic region of the
NHDPlusV2. A catchment defines the area that flows to each stream segment in the NHDPlusV2 dataset. Catchments within the Chesapeake Bay have an average size of $2 \mathrm{~km}^{2}$ and drain stream features with an average length of 1.4 kilometers $(\mathrm{km})$. A total of 83,632 catchments extracted from the mid-Atlantic region overlap the Chesapeake Bay watershed. The NHDPlusV2 maintains a set of value added attributes (VAA) for each stream segment and drainage area in the conterminous United States (McKay and others, 2017) and were used where available. If the values were not available from the NHDPlusV2 VAA tables, the catchment values were calculated using common geospatial-overlay zonal statistical techniques.

The Watershed Boundary Dataset is a national dataset that defines drainage area delineations at multiple nested scales. The largest area is a 2-digit hydrologic unit, which represents 21 major hydrologic regions within the United States. The smallest national areal delineation is a subwatershed scale, defined here as a 12-digit hydrologic unit (HUC12). There are over 160,000 subwatersheds within the United States, and 1,966 HUC12s are in the Chesapeake Bay watershed and within the model area (U.S. Geological Survey and U.S Department of Agriculture, Natural Resources Conservation Service, 2013).

\section{Mean Annual Flow}

The mean annual-flow estimates were retrieved from the NHDPlusV2 Extended Unit Runoff Method (EROMExtenstion) table (Horizon Systems Corporation, 2017). Incremental flow from runoff, in cubic feet per second $\left(\mathrm{ft}^{3} / \mathrm{s}\right.$ ) (field QIncr0001A), was used because it closely represents the flow that enters the stream segment from natural overland flow. Natural overland flow is water that would enter the stream after a potential loss to overland infiltration into the subsurface. The QIncr0001A values are estimated flow for each stream segment in the NHDPlusV2, based on the runoff model.

\section{Percent Developed and Percent Agricultural}

Percentages of a land cover class within a catchment were obtained from the National Land Cover Dataset (NLCD) 2011-extension VAA tables (Horizon Systems Corporation, 2017; Homer and others, 2015). The land cover classes were summarized for each catchment in the same way the data were processed for input into the regression model as described above, creating three land cover classes: "percent developed," "percent agricultural," and "percent other" (fig. 3).

\section{Geology}

The geologic units match the units used to develop the regression model (fig. 4). The geologic component that composes the majority of the NHDPlusV2 catchment area was used as the geology type (U.S. Geological Survey, 2003). Each catchment was coded for each geologic unit. The geologic unit 
Table 2. Long-term mean and median baseflow values, actual and estimated, by regression model and geologic unit.

$[$ Other $=$ values for siliciclastic, sandstone and semiconsolidated sand geologic units; conc. = concentration; $\mathrm{mg} \mathrm{N} / \mathrm{L}=$ milligrams of nitrate per liter]

\begin{tabular}{lccccc}
\hline \multicolumn{1}{c}{ Geologic unit } & $\begin{array}{c}\text { Number of sites } \\
\text { per geologic } \\
\text { unit }\end{array}$ & $\begin{array}{c}\text { Mean nitrate } \\
\text { conc. in stream } \\
\text { at baseflow, } \\
\text { actual } \\
\text { (mg N/L) }\end{array}$ & $\begin{array}{c}\text { Median nitrate } \\
\text { conc. in stream } \\
\text { at baseflow, } \\
\text { actual } \\
\text { (mg N/L) }\end{array}$ & $\begin{array}{c}\text { Mean nitrate } \\
\text { conc. in stream } \\
\text { at baseflow, } \\
\text { estimated } \\
\text { (mg N/L) }\end{array}$ & $\begin{array}{c}\text { Median nitrate } \\
\text { conc. in stream } \\
\text { at baseflow, } \\
\text { estimated } \\
\text { (mg N/L) }\end{array}$ \\
\hline Carbonate & 13 & 7.7 & 7.9 & 7.7 & 7.9 \\
Delmarva & 9 & 2.7 & 1.4 & 2.7 & 2.4 \\
Igneous and metamorphic & 34 & 1.7 & 1.3 & 1.7 & 1.5 \\
Sandstone and carbonate & 52 & 1.5 & 0.9 & 1.5 & 1.3 \\
Other & 48 & 0.7 & 0.4 & 0.8 & 0.6 \\
\hline
\end{tabular}

for the catchment was coded as either a "1" to indicate that the catchment was predominantly that geologic type or a " 0 " to indicate that it was not.

\section{Baseflow Index}

The estimate of the percentage of total annual flow due to baseflow was sourced from the Baseflow Index (BFI) dataset for the conterminous United States (Wolock, 2003). The BFI values were averaged for each NHDPlusV2 catchment using a zonal statistics overlay technique.

\section{Catchment Area}

The catchment area was calculated as the area, in square kilometers $\left(\mathrm{km}^{2}\right)$, of the NHDPlusV2 catchment that drains into each stream segment. The average size of the 83,632 catchments within the Chesapeake Bay watershed is $2.0 \mathrm{~km}^{2}$. The median size of the catchments is $1.2 \mathrm{~km}^{2}$. Small catchments (less than $0.5 \mathrm{~km}^{2}$ ) are usually located at confluences and throughout the watershed. Large catchments (greater than $50 \mathrm{~km}^{2}$ ) are often located in long river valleys.

\section{Calculating Median Nitrate Concentrations in Baseflow, Loads, and Yields From Groundwater}

Each catchment within the Chesapeake Bay watershed was populated using the variables from table 3 . The multiple regression equation (the regression coefficients and intercept from table 1, rewritten as equation 1 using the catchment variable notations from table 3) was applied to each catchment to calculate a preliminary baseflow nitrate concentration. An adjustment was made if a concentration value was less than 0 ; the value was adjusted to equal $0.001 \mathrm{mg} \mathrm{N} / \mathrm{L}$. A second adjustment was applied to areas with 0 "percent developed" and 0 "percent agricultural" lands. If one of these catchments had baseflow concentration values greater than 0.1 , the value was reduced to $0.1 \mathrm{mg} \mathrm{N} / \mathrm{L}$ based on typical background concentrations of total nitrogen in the region (Smith and others, 2003). The concentration was not changed when the value was less than $0.1 \mathrm{mg} \mathrm{N} / \mathrm{L}$ for the undeveloped catchments. These adjustments affected 7 percent of the total area of the Chesapeake Bay watershed. The results shown in figure $7 A$ indicate the following:
Figure 5. Graph showing actual median nitrate concentrations in baseflow compared with estimated median nitrate concentrations in baseflow, based on model results.

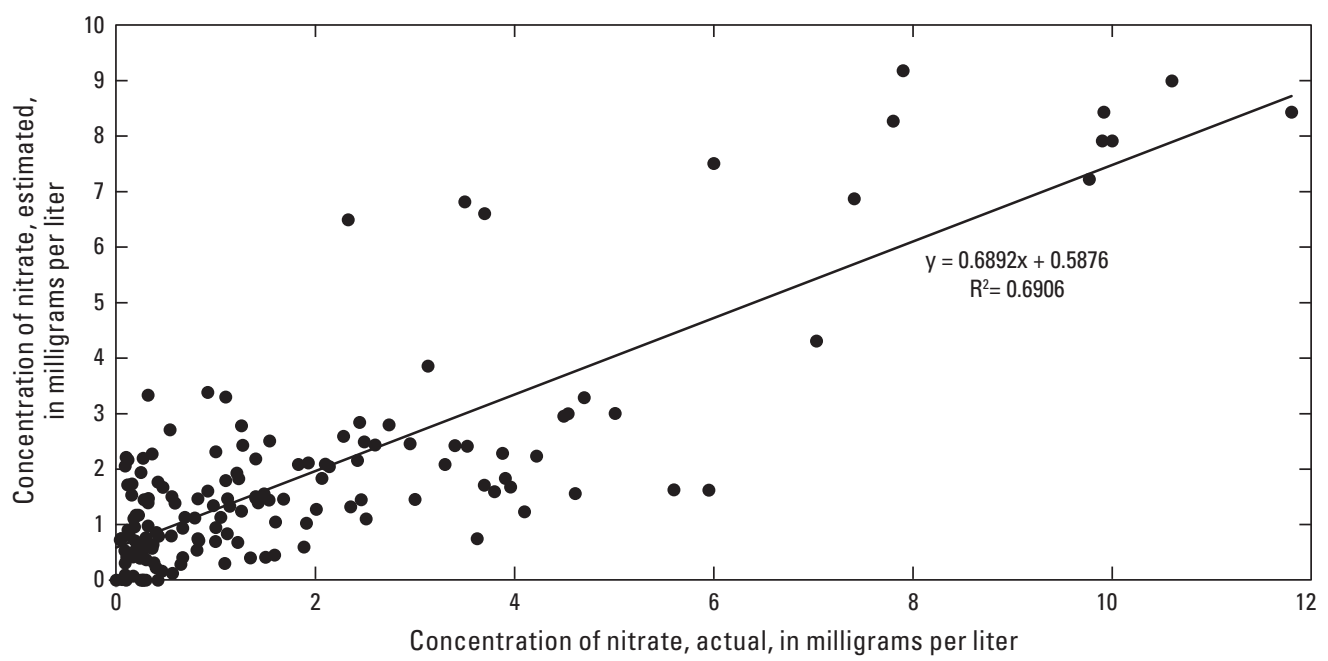




$$
\begin{gathered}
\text { Median nitrate concentration in baseflow }(\mathrm{mg} \mathrm{N} / \mathrm{L})=-0.13020+(\mathrm{PctDev} * 0.00870)+(\operatorname{PctAg} * 0.03463) \\
+(\text { Carb } * 6.05708)+(\text { SandCarb } * 0.49983)+(\text { IgMet } * 0.84704)+(\text { Delmarva } * 1.36573) .
\end{gathered}
$$

The annual median nitrate load from groundwater to streams is the product of the estimated baseflow nitrate concentrations multiplied by the total annual streamflow, multiplied by the fraction of total annual flow due to baseflow. Since a load is not normalized to an area, some artifacts can be seen within the original quadrangles that were the source of hydrography information for the NHDPlusV2. In some of the source quadrangles, fewer hydrography lines were delineated; therefore, catchments tend to have larger spatial areas. Loads appear to be higher in the locations where the rectangular quadrangles are visible, but this is due more to areal difference than potential areas of higher contamination. The results shown in figure $7 B$ indicate the following:

Annual nitrate load in groundwater to the stream $(\mathrm{kg} / \mathrm{yr})=($ median nitrate concentration in baseflow $(\mathrm{mg} \mathrm{N} / \mathrm{L})$

$$
\text { *.001)*(QincrA in } \left.\mathrm{ft}^{3} / \mathrm{s}\right) *(\mathrm{BFI} / 100) *(0.0283 * 31,536,000)
$$

where multipliers are applied as conversion factors for nitrate concentrations from milligrams of nitrate per liter to kiligrams of nitrate per liter and for streamflow from cubic feet per second $\left(\mathrm{ft}^{3} / \mathrm{s}\right)$ to annual flow in liters per year; $\mathrm{kg} / \mathrm{yr}$ is kilograms per year. The nitrate yield from groundwater to the stream was calculated by dividing the annual nitrate load from groundwater to the stream by the catchment area (AreaSqKm). The results shown in figure $7 C$ indicate the following:

Annual nitrate yield from groundwater to the stream $\left(\mathrm{kg} \mathrm{N} / \mathrm{km}^{2}\right)=($ annual nitrate load from groundwater to the stream, $\mathrm{kg} / \mathrm{yr}) /\left(\right.$ AreaSqKm, $\left.\mathrm{km}^{2}\right)$,

where $\mathrm{kg} / \mathrm{yr}$ is kilograms per year, $\mathrm{km}^{2}$ is square kilometers.

In figure 8, loads and yields are aggregated to HUC12 units by assigning individual catchments to the HUC12 unit, first by assigning the outlet catchment to the HUC12 and then by assigning all other catchments to a HUC12 based on the majority of the HUC12 area that the catchment overlapped. Once the HUC12 was assigned to each catchment, area and loads from the catchments were summarized by HUC12 unit. The yields are calculated by dividing the summed loads by the total catchment areas assigned to that $\mathrm{HUC12}$.

A data release containing the shapefile data and metadata for the (1) water-quality sites used to build the model, (2) catchments with attributes for the source data and calculated concentration, load and yield of nitrate from groundwater to streams, and (3) HUC12 units with calculated load and yield of nitrate from groundwater to streams for the Chesapeake Bay watershed is available in Terziotti and others (2017).

Figure 6. Boxplots of actual and estimated baseflow concentrations of nitrate by geologic unit. $(\mathrm{A}=$ actual; $\mathrm{E}=$ estimated; Other $=$ the combined values for the geologic units siliciclastic, sandstone and semiconsolidated sand)

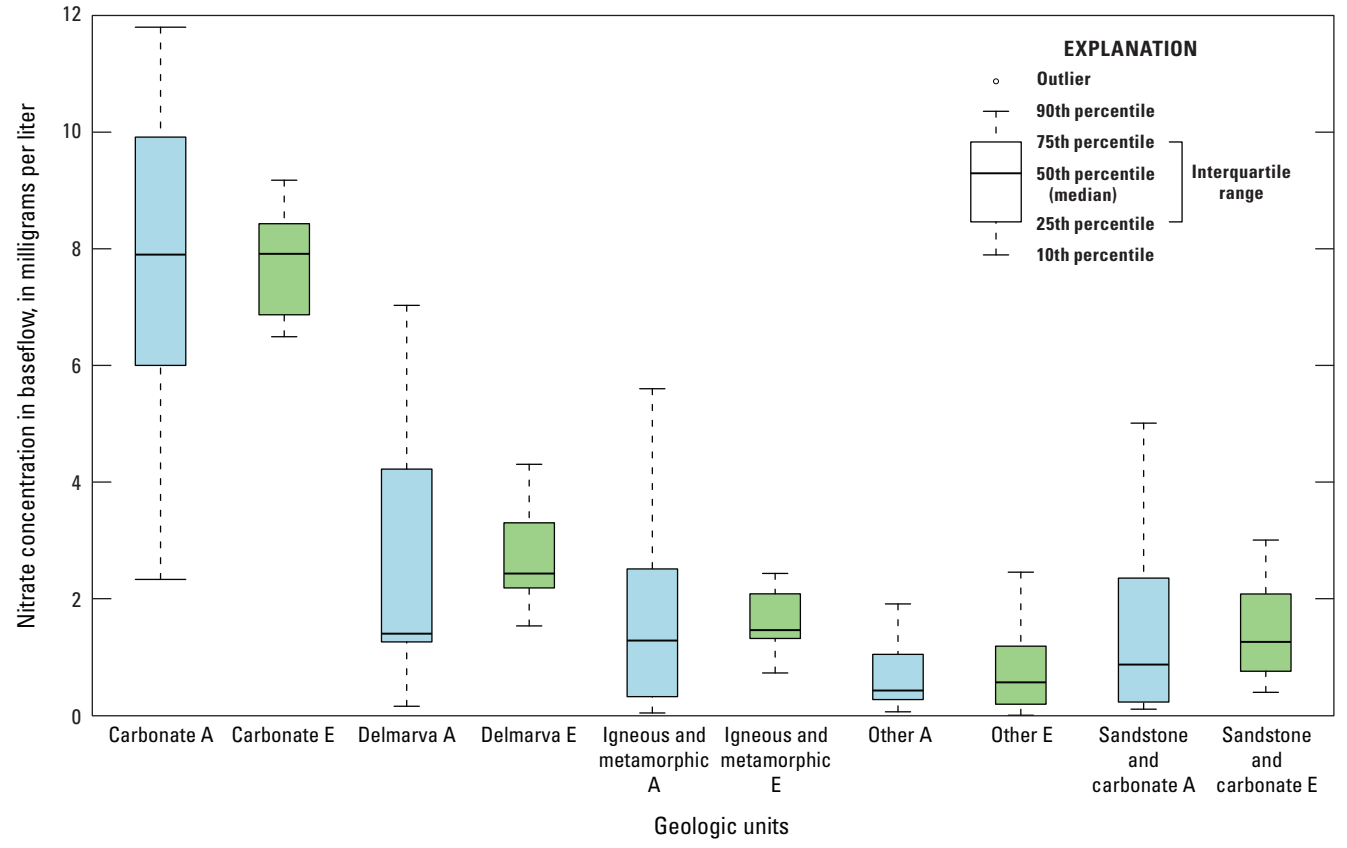


Table 3. Variables used to estimate median nitrate concentration in baseflow for catchments within the Chesapeake Bay watershed.

[Area is given in square kilometers $\left(\mathrm{km}^{2}\right)$; flow is given in cubic feet per second $\left(\mathrm{ft}^{3} / \mathrm{s}\right)$ ]

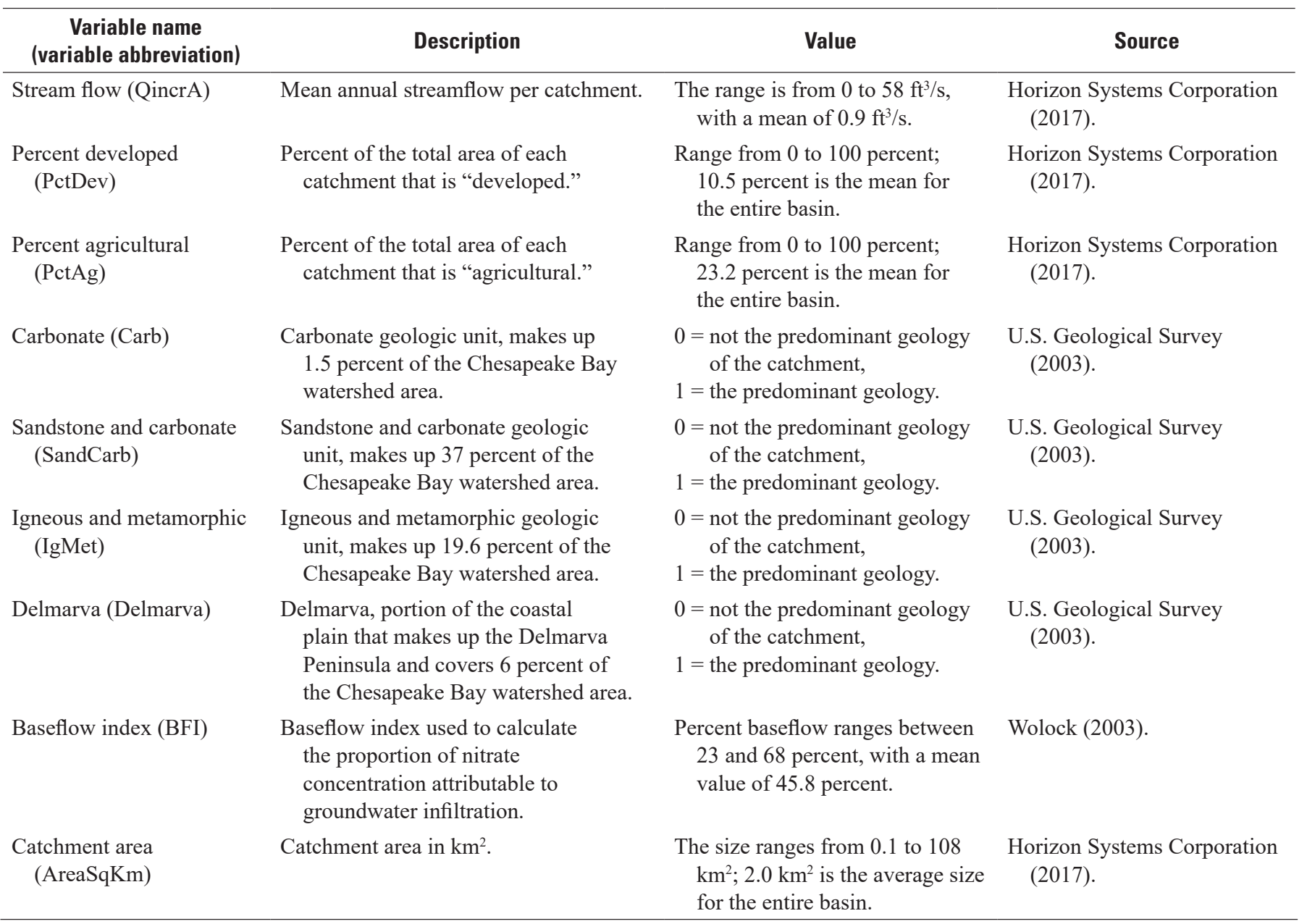

\section{Results of Estimated Nitrate Loads and Yields From Groundwater to Streams}

The nitrate loads and yields from groundwater to streams in the Chesapeake Bay watershed are shown in figure 8. The maps show that the highest potential of elevated nitrate yields from groundwater is located in the carbonate unit within the southeast corner of Pennsylvania and within the narrow belts in both the northern and central portions of the watershed. Watersheds in the Delmarva Peninsula and in those areas underlain by the igneous and metamorphic unit in the southcentral portions of the watershed also show high yields of groundwater nitrate. Modeled baseflow nitrate yields averaged $1,736 \mathrm{~kg} / \mathrm{km}^{2}$ per year in the carbonate unit, $354 \mathrm{~kg} / \mathrm{km}^{2}$ per year in the Delmarva unit, and $302 \mathrm{~kg} / \mathrm{km}^{2}$ per year in the igneous and metamorphic unit. Other studies show that groundwater plays a major role in contributing contaminants to many of the tributaries to the Bay (Denver and others, 2004; Debrewer and others, 2008; Sanford and Pope, 2013).
The annual nitrate yields from the groundwater model have spatial patterns similar to the total nitrogen yields estimated by the Chesapeake Bay nitrogen SPAtially Referenced Regressions On Watershed attributes (SPARROW) waterquality model (Ator and others, 2011). Figure 9 uses the same range of values for each model, but since SPARROW represents the yield of nitrate from all sources, and the groundwater model only represents the groundwater contribution, the SPARROW yields are greater. The spatial pattern of low and high yields from the groundwater and SPARROW models are strongly similar throughout most of the watershed. This similarity suggests that a significant percentage of the annual yield of total nitrate could be from groundwater sources. In areas with large population centers, the groundwater nitrate yields are low compared with the total yields shown in the SPARROW model (fig. 9). This difference might be due to point sources and (or) the high number of impervious surfaces in urbanized areas, which afford few opportunities for contaminants to enter the groundwater and return to the streams as baseflow. 


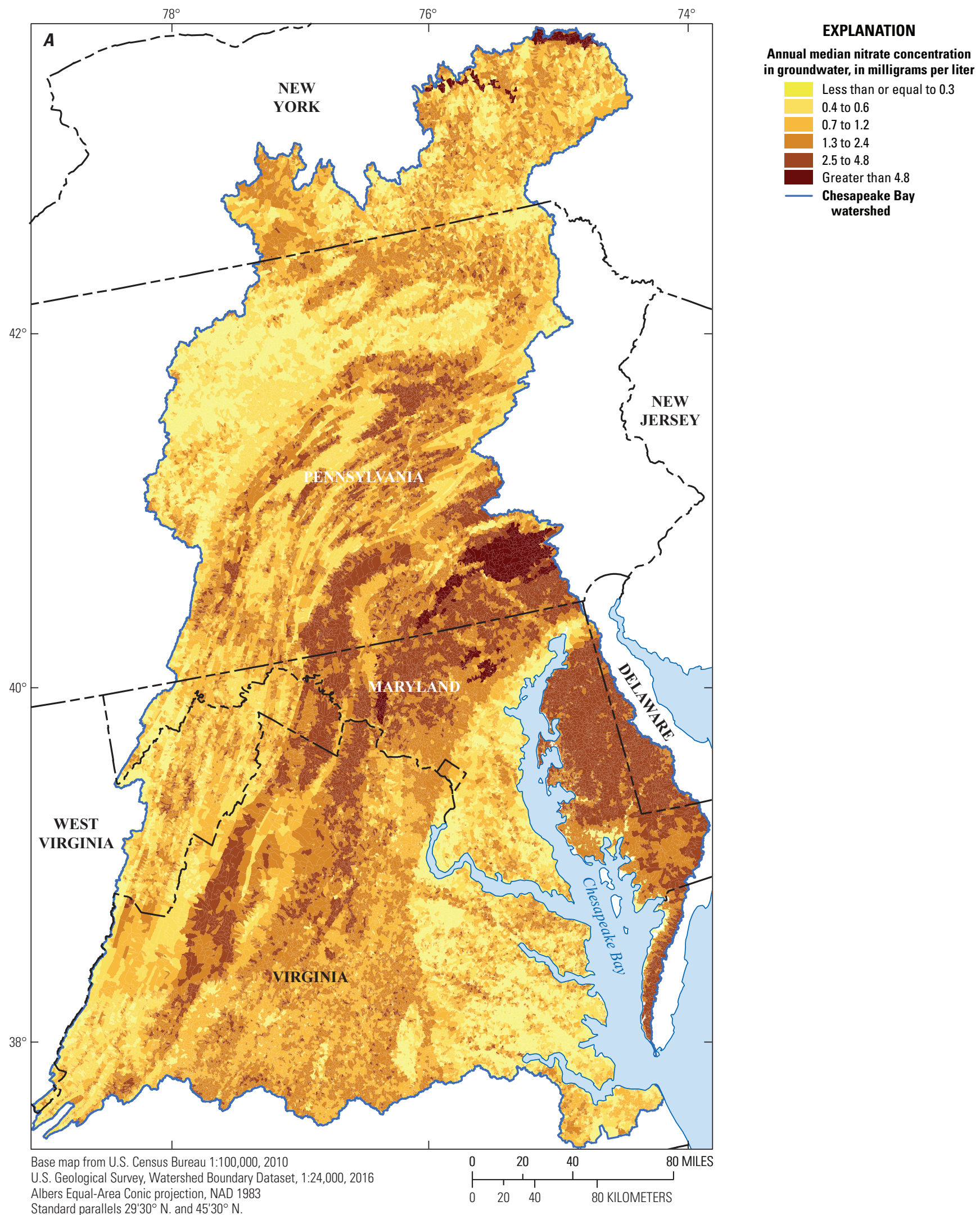

Standard parallels $29^{\prime} 30^{\circ} \mathrm{N}$. and $45^{\prime} 30^{\circ} \mathrm{N}$.

Central Meridian $96^{\circ} 00^{\prime} \mathrm{W}$.

Figure 7. Maps showing estimated groundwater nitrate for each catchment within the Chesapeake Bay watershed, $(A)$ annual median concentration, $(B)$ annual load from groundwater to streams, and $(C)$ annual yield from groundwater. 


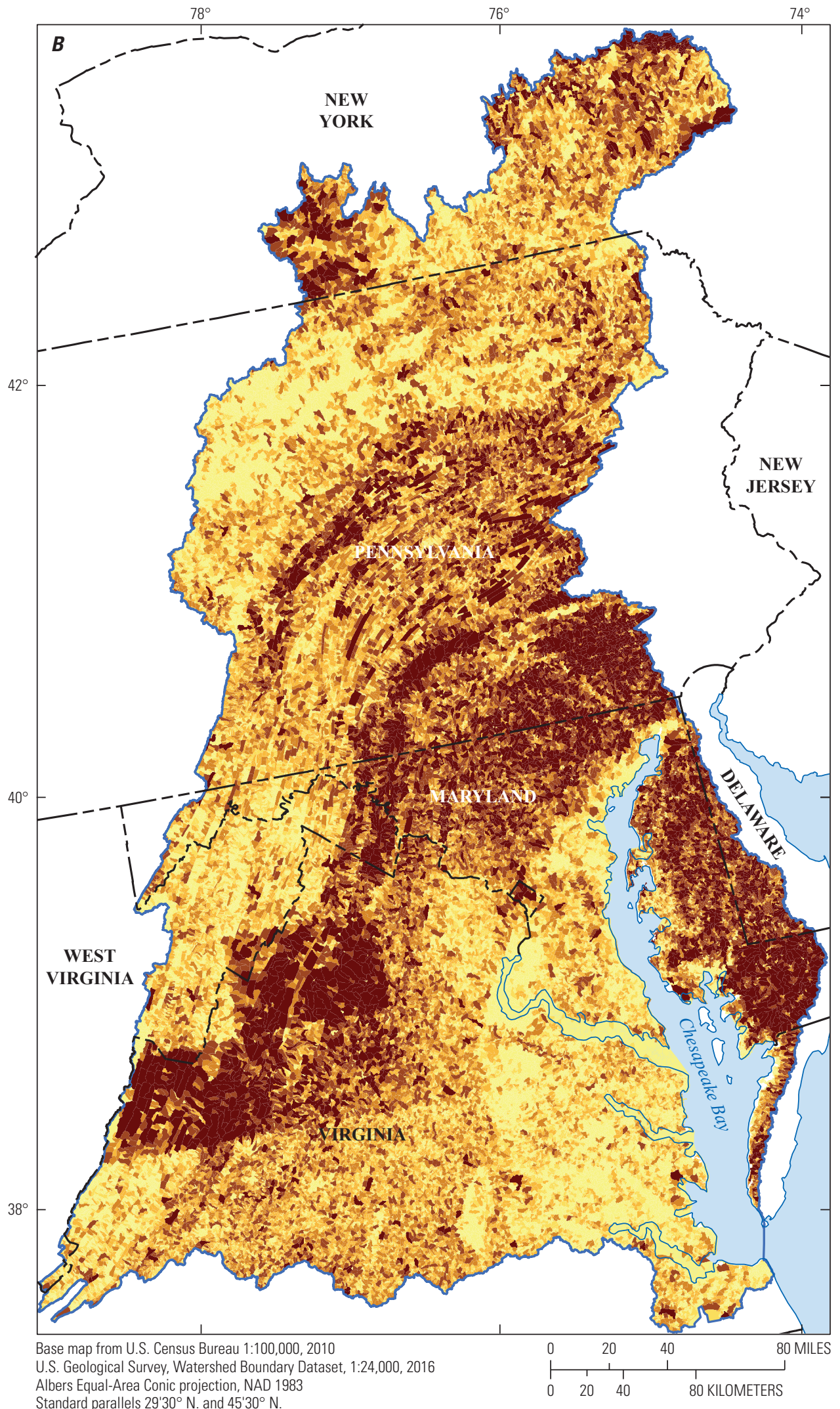

\section{EXPLANATION}

Annual nitrate load from groundwate to the stream, in kilograms per year

Less than or equal to 150.0

150.1 to 300.0

300.1 to 600.0

600.1 to $1,200.0$

$1,200.1$ to $2,400.0$

Greater than 2,400.0

Chesapeake Bay watershed

parallels $2930^{\circ} \mathrm{N}$. and $4530^{\circ} \mathrm{N}$

Central Meridian $96^{\circ} 00^{\prime} \mathrm{W}$.

Figure 7. Continued. 


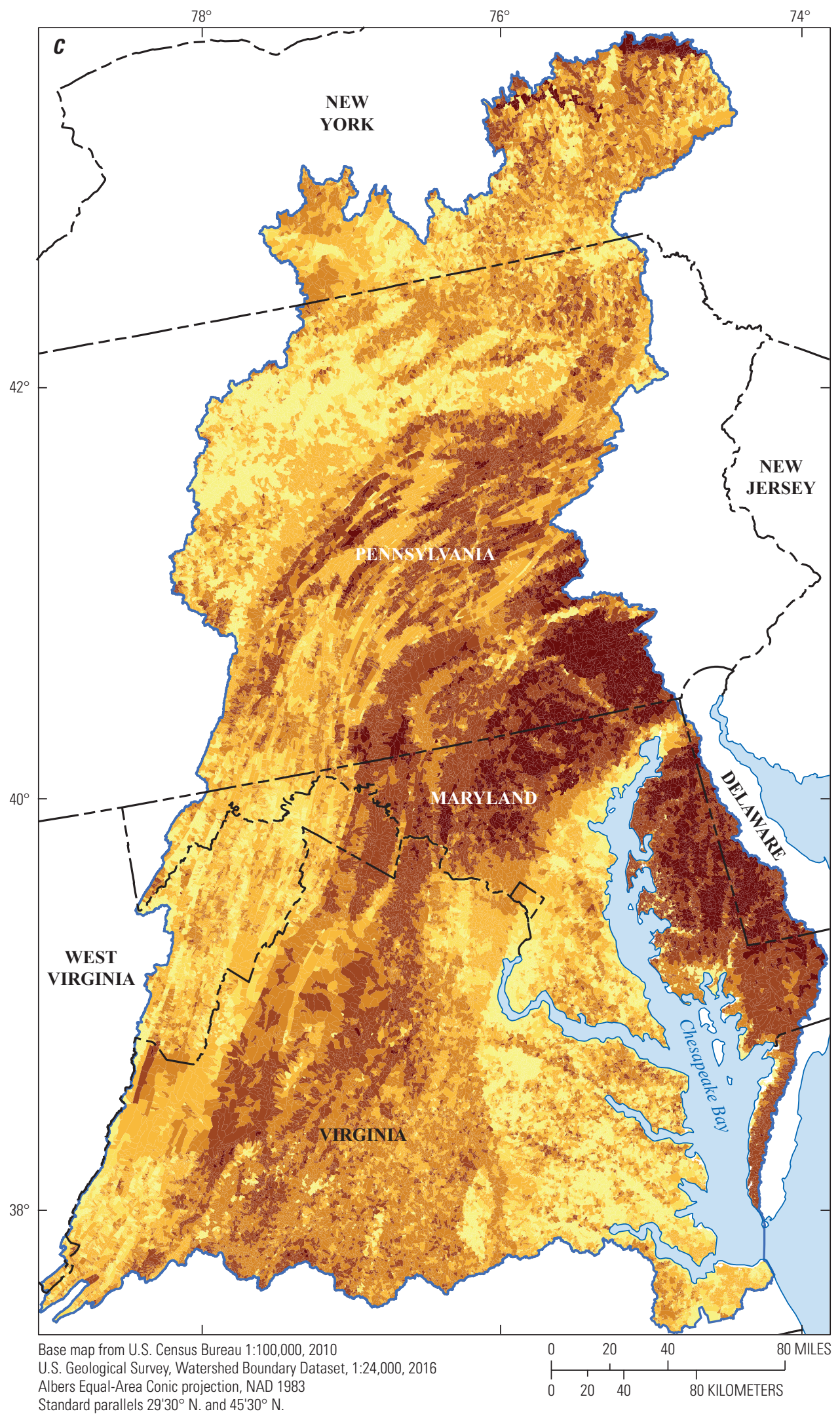

EXPLANATION

Annual nitrate yield from groundwater to the stream, in kilograms per square kilometer

Less than or equal to 40.0

40.1 to 80.0

80.1 to 160.0

160.1 to 320.0

320.1 to 640.0

Greater than 640.0

Chesapeake Bay

watershed

Central Meridian $96^{\circ} 00^{\prime} \mathrm{W}$.

Figure 7. Continued. 


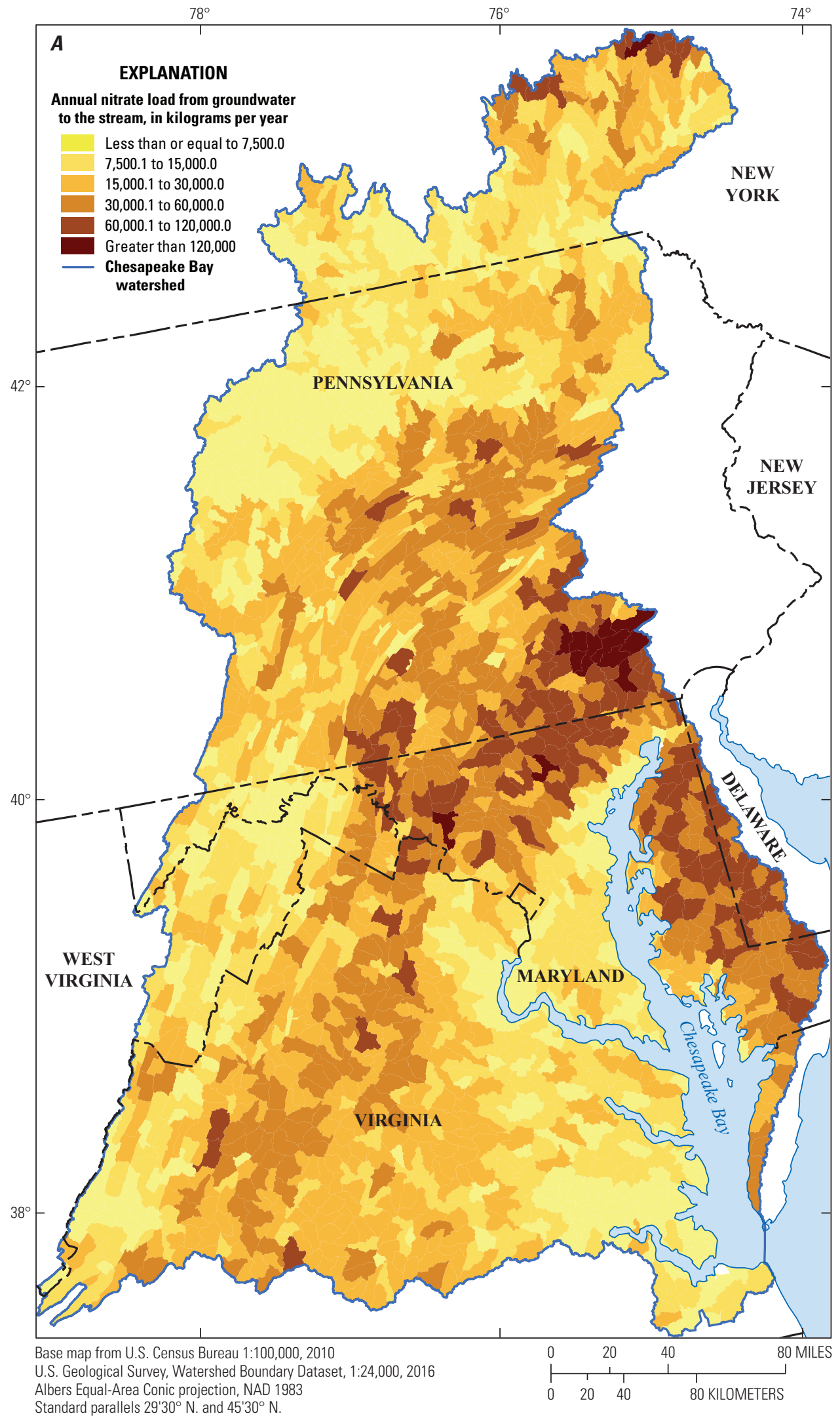

Standard paralle $29^{\prime} 30^{\circ} \mathrm{N}$ and $45^{\prime} 30^{\circ} \mathrm{N}$

Central Meridian $96^{\circ} 00^{\prime} \mathrm{W}$.

Figure 8. Maps showing estimated groundwater nitrate for each catchment within the Chesapeake Bay watershed, $(A)$ annual load from groundwater to streams, and $(B)$ annual yield from groundwater. 


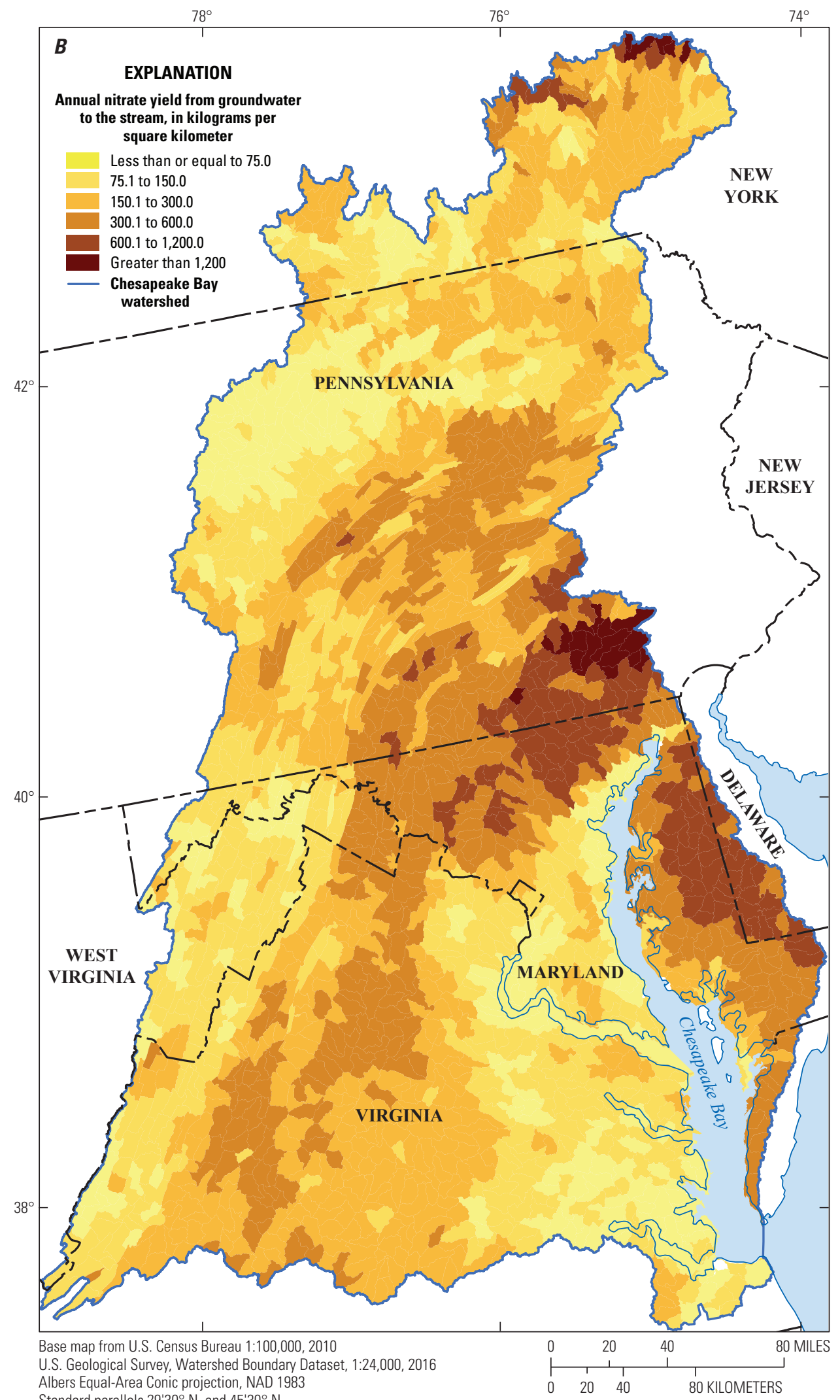

Albers Equal-Area Conic projection, NAD 1983

Standard parallels $29^{\prime} 30^{\circ} \mathrm{N}$. and $45^{\prime} 30^{\circ} \mathrm{N}$.

Central Meridian $96^{\circ} 00^{\prime} \mathrm{W}$.

Figure 8. Continued. 
Annual nitrate yield from groundwater to the stream, groundwater model

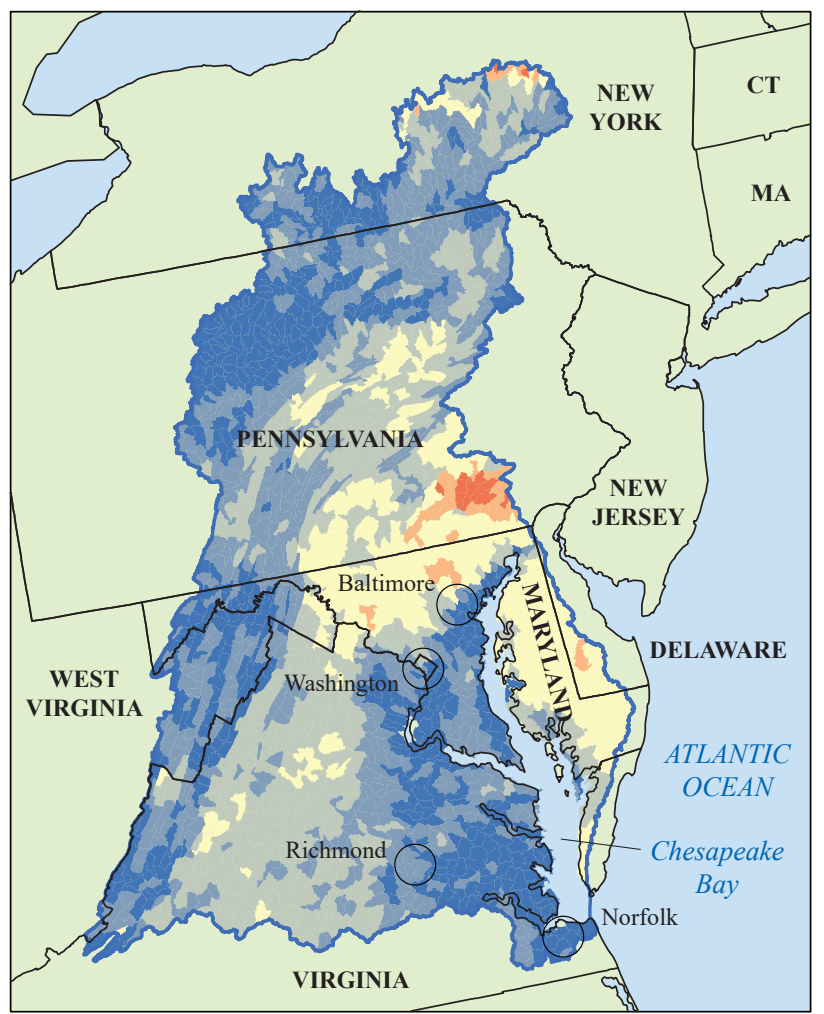

Base map from U.S. Census Bureau 1:100,000, 2010

U.S. Geological Survey, Watershed Boundary Dataset, 1:24,000, 2016 Albers Equal-Area Conic projection, NAD 1983

Standard parallels $29^{\prime} 30^{\circ} \mathrm{N}$. and $45^{\prime} 30^{\circ} \mathrm{N}$.

Central Meridian $96^{\circ} 00^{\prime}$ W.
Annual nitrate yield,

SPARROW model 
The calibrated model explained 69 percent of the concentration of nitrate in baseflow.

The model coefficients were used to predict baseflow nitrate concentration values throughout the entire watershed. Median nitrate concentrations in baseflow and the annual loads and yields of nitrate from groundwater to streams were calculated for each catchment of the NHDPlusV2 within the Chesapeake Bay watershed. The annual nitrate loads and yield values from groundwater were also aggregated to an HUC12 unit. The results, when compared with the results of the SPARROW model, show similar spatial patterns in areas not highly urbanized. The groundwater model showed similar but lower yields, suggesting that groundwater is a major source of nitrogen for streams in the Chesapeake Bay watershed.

The resultant datasets and maps can be useful in providing a way to target areas for urban and agricultural bestmanagement strategies where groundwater sources contribute a substantial amount to the total concentration of nitrate in streams. Also, this approach can be reproduced for other areas of the country if sufficient observations of nitrate concentrations in streams at baseflow are available.

\section{Acknowledgments}

This research was funded by the U.S. Geological Survey's National Water-Quality Assessment Project. The authors appreciate the insightful review comments provided by colleagues John Clune and Mark Nardi, and the assistance from the editors that handled this report.

\section{References Cited}

Ator, S.W., Brakebill, J.W., and Blomquist, J.D., 2011, Sources, fate, and transport of nitrogen and phosphorus in the Chesapeake Bay watershed-An empirical model: U.S. Geological Survey Scientific Investigations Report 2011-5167, 27 p. [Also available at https://pubs.usgs.gov/ $\operatorname{sir} / 2011 / 5167 /]$

Chesapeake Bay Program, 2017a, The Chesapeake Bay watershed: Chesapeake Bay Program website, accessed April 6, 2017, at http://www.chesapeakebay.net/discover/ baywatershed.

Chesapeake Bay Program, 2017b, Bay barometer 20152016 - Health and restoration in the Chesapeake Bay watershed: Annapolis, Md., Chesapeake Bay Program, 12 p., accessed August 6, 2017, at http://www.chesapeakebay.net/ documents/2015-2016_Bay_Barometer.pdf.

Clune, J.W., and Denver, J.M., 2012, Residence time, chemical and isotopic analysis of nitrate in the groundwater and surface water of a small agricultural watershed in the Coastal Plain, Bucks Branch, Sussex County, Delaware: U.S. Geological Survey Scientific Investigations Report 2012-5235, 15 p., accessed August 13, 2017, at http://pubs.usgs.gov/sir/2012/5235.
Debrewer, L.M., Ator, S.W., and Denver, J.M., 2008, Temporal trends in nitrate and selected pesticides in midAtlantic ground water: Journal of Environmental Quality Abstract-Special submissions, v. 37, no. 5, supplement, p. S-296-S-308, accessed Oct 3, 2017, at https://doi.org/10.2134/jeq2007.0664.

Denver, J.M., Ator, S.W., Debrewer, L.M., Ferrari, M.J., Barbaro, J.R., Hancock, T.C., Brayton, M.J., and Nardi, M.R., 2004, Water quality in the Delmarva Peninsula, Delaware, Maryland, and Virginia, 1999-2001: U.S. Geological Survey Circular 1228, 40 p., accessed August 13, 2017, at https://pubs.usgs.gov/circ/2004/1228/.

Dubrovsky, N.M., Burow, K.R., Clark, G.M., Gronberg, J.M., Hamilton P.A., Hitt, K.J., Mueller, D.K., Munn, M.D., Nolan, B.T., Puckett, L.J., Rupert, M.G., Short, T.M., Spahr, N.E., Sprague, L.A., and Wilber, W.G., 2010, The quality of our Nation's waters-Nutrients in the Nation's streams and groundwater, 1992-2004: U.S. Geological Survey Circular 1350, 174 p. [ Available at https://pubs.usgs.gov/ circ/1350/]

Duff, J.H., Tesoriero, A.J., Richardson, W.B., Strauss, E.A., and Munn, M.D., 2008, Whole-stream response to nitrate loading in three streams draining agricultural landscapes: Journal of Environmental Quality, v. 37, p. 1133-1144, accessed August 13, 2017, at https://doi.org/10.2134/ jeq2007.0187.

Dupré, D.H, Scott, J.C., Clark, M.L., Canova, M.G, and Stoker, Y.E., 2013, User's manual for the National Water Information System of the U.S. Geological Survey-WaterQuality System, Version 5.0: U.S. Geological Survey OpenFile Report 2013-1054, 730 p., accessed June 22, 2017, at https://pubs.usgs.gov/of/2013/1054/pdf/OFR2013-1054_ NWIS_ver5.pdf.

Eckhardt, K., 2005, How to construct recursive digital filters for baseflow separation: Hydrological Processes, v. 19, no. 2, p. 507-515, accessed August 13, 2017, https://doi.org/10.1002/hyp.5675.

Greene, E.A., LaMotte, A.E., and Cullinan, K.-A., 2005, Ground-water vulnerability to nitrate contamination at multiple thresholds in the mid-Atlantic region using spatial probability models: U.S. Geological Survey Scientific Investigations Report 2004-5118, accessed August 13, 2017, at https://pubs.er.usgs.gov/publication/ sir20045118.

Homer, Colin; Dewitz, Jon; Yang, Limin; Jin, Suming; Danielson, Patrick; Xian, George; Coulston, John; Herold, Nathaniel; Wickham, James; and Megown, Kevin, 2015, Completion of the 2011 National Land Cover Database for the conterminous United States - Representing a decade of land cover change information: Photogrammetric Engineering and Remote Sensing, v. 81, no. 5, p. 345-354. [Available at https://doi.org/10.14358/PERS.81.5.345] 
Horizon Systems Corporation, 2017, NHDPlusV2 Data: Horizon Systems NHDPlus Version 2 Data web page, accessed April 5, 2017, at http://www.horizon-systems.com/ NHDPlus/NHDPlusV2_data.php.

Langland, M.J., Blomquist, J.D., Moyer, D.L., Hyer, K.E., and Chanat, J.G., 2013, Total nutrient and sediment loads, trends, yields, and nontidal water-quality indicators for selected nontidal stations, Chesapeake Bay watershed, 1985-2011: U.S. Geological Survey Open-File Report 2013-1052, 51 p., available at http://pubs.usgs.gov/ of $/ 2013 / 1052 /$.

Langland, M.J., Lietman, L.P., and Hoffman, Scott, 1995, Synthesis of nutrient and sediment data for watersheds within the Chesapeake Bay drainage basin: U.S. Geological Survey Water-Resources Investigations Report 95-4233, 121 p., accessed August 13, 2017, at https://pubs.er.usgs.gov/publication/wri954233/.

Lyerly, C.M., Hernández Cordero, A.L., Foreman, K.L., Phillips, S.W., Dennison, W.C., eds., 2014, New insightsScience-based evidence of water quality improvements, challenges, and opportunities in the Chesapeake: [Cambridge, Md., University of Maryland Center for Environmental Science; Annapolis, Md., Chesapeake Bay Program], 46 p., accessed August 13, 2017, at http://ian.umces.edu/press/reports/publication/438/ new_insights_science_based_evidence_of_water_quality improvements_challenges_and_opportunities_in_the _chesapeake_2014-02-24/.

McKay, L., Bondelid, T., Dewald, T., Johnston, J., Moore, R., and Rea, A., [2017], NHDPlus Version 2 (Data model version 2.1) - User guide: Washington, D.C., Environmental Protection Agency, accessed August 13, 2017, at ftp://ftp.horizon-systems.com/NHDplus/NHDPlusV21/ Documentation/NHDPlusV2_User_Guide.pdf.

Pew Charitable Trusts, 2017, Reforming industrial animal agriculture fact sheet: Philadelphia, Pa., The Pew Charitable Trusts, 4 p., accessed June 21, 2017, at http://www.pewtrusts.org/en/research-and-analysis/ fact-sheets/2012/02/13/cleaning-up-the-chesapeakebay\#sthash.LDt679FM.dpuf.

PRISM Climate Group, 2017, PRISM climate data: Oregon State University web page, accessed August 13, 2017, at http://prism.oregonstate.edu.

Raffensperger, J.P., Baker, A.C., Blomquist, J.D., and Hopple, J.A., 2017, Hydrograph-separation results for 225 streams in the Chesapeake Bay watershed derived using PART, HYSEP (Fixed, local minimum, slide), BFI, and a recursive digital filter using streamflow data ranging from 1913 through 2016: U.S. Geological Survey data release, accessed August 13, 2017, at https://doi.org/10.5066/ F757194G.
Sanford, W.E. and Pope, J.P., 2013, Quantifying groundwater's role in delaying improvements to Chesapeake Bay water quality: Environmental Science and Technology, v. 47, no. 23 , p. 13,330-13,338, accessed August 13, 2017, https://doi.org/10.1021/es401334k.

Santhi, C., Allen, P.M., Muttiah, R.S., Arnold, J.G., and Tuppad, P., 2008, Regional estimation of base flow for the conterminous United States by hydrologic landscape regions: Journal of Hydrology, v. 351, nos. 1-2, p. 139-153, accessed August 13, 2017, at https://doi.org/10.1016/ j.jhydrol.2007.12.018.

SAS Institute, Inc., 2011, SAS/STAT 9.3 User's Guide: SAS/ STAT 9.3 Software web page, accessed November 14, 2017, at http://support.sas.com/documentation/cdl/en/ statug/63962/HTML/default/viewer.htm.

Shedlock, R.J., Denver, J.M., Hayes, M.A., Hamilton, P.A., Koterba, M.T., Bachman, L.J., Phillips, P.J., Banks, W.S.L., 1999, Water-quality assessment of the Delmarva Peninsula, Delaware, Maryland, and Virginia - Results of investigations, 1987-91: U.S. Geological Survey Water-Supply Paper 2355-A, 41 p., accessed August 13, 2017, at https://pubs.er.usgs.gov/publication/wsp2355A.

Smith, R.A., Alexander, R.B., and Schwarz, G.E., 2003, Natural background concentrations of nutrients in streams and rivers of the conterminous United States: Environmental Science and Technology, v. 37, no. 14, p. 3039-3047, accessed August 13, 2017, at https://doi.org/10.1021/es020663b.

Terziotti, Silvia, and Hopple, J.A., 2017, Datasets and metadata for estimates of nitrate loads and yields from groundwater to streams in the Chesapeake Bay watershed based on land use and geology: U.S. Geological Survey data release, https://doi.org/10.5066/F79G5KP4.

Tesoriero, A.J., Duff, J.H., Saad, D.A., Spahr, N.E., and Wolock, D.M., 2013, Vulnerability of streams to legacy nitrate sources: Environmental Science and Technology, v. 47, no. 8, p. 3623-3629, accessed August 13, 2017, at https://doi.org/10.1021/es305026x.

Tesoriero, A.J., Terziotti, Silvia, and Abrams, D.B., 2015, Predicting redox conditions in groundwater at a regional scale: Environmental Science and Technology, v. 49, no. 16, p. 9657-9664, accessed August 13, 2017, at https://doi.org/10.1021/acs.est.5b01869.

U.S. Department of Agriculture, Economic Research Service, 2016, Nutrient management web page: U.S. Department of Agriculture website, accessed August 13, 2017, at https://www.ers.usda.gov/topics/farm-practices-management/crop-livestock-practices/nutrient-management/. 


\section{Estimates of Nitrate From Groundwater to Streams in the Chesapeake Bay Watershed}

U.S. Environmental Protection Agency, Office of Water, 2015, A compilation of cost data associated with the impacts and control of nutrient pollution: Washington, D.C., U.S. Environmental Protection Agency, EPA 820-F-15096, accessed August 13, 2017, at https:/www.epa.gov/ sites/production/files/2015-04/documents/nutrient-economics-report-2015.pdf.

U.S. Geological Survey, 2003, Principal aquifers of the 48 conterminous United States, Hawaii, Puerto Rico, and the U.S. Virgin Islands: U.S. Geological Survey dataset, accessed August 13, 2017, at https://water.usgs.gov/ogw/ aquifer/map.html.

U.S. Geological Survey, 2012, National Water Information System-Web interface: USGS water-quality data for the Nation website, accessed October 14, 2014, at https://doi.org/10.5066/F7P55KJN.
U.S. Geological Survey and U.S. Department of Agriculture, Natural Resources Conservation Service, 2013, Federal Standards and Procedures for the National Watershed Boundary Dataset (WBD) (4th ed.): U.S. Geological Survey Techniques and Methods 11-A3, 63 p., accessed August 13, 2017, at http://pubs.usgs.gov/tm/tm11a3/.

Winter, T.C., Harvey, J.W., Franke, O.L., and Alley, W.M., 1998, Ground water and surface water-A single resource: U.S. Geological Survey Circular 1139, 79 p. [Also available at https://pubs.usgs.gov/circ/circ1139/]

Wolock, D.M., 2003, Base-flow index grid for the conterminous United States: U.S. Geological Survey Open-File Report 03-263 (digital dataset), accessed August 13, 2017, at http://water.usgs.gov/lookup/getspatial?bfi48grd. 



\section{$\frac{\mathbb{2}}{3}$}

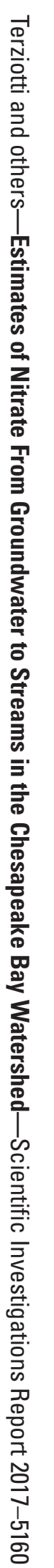

